\title{
The Depiction of Heaven and Hell in the Karmawibangga Reliefs of Borobudur Temple: An Overview of Character Education
}

DOI: https://doi.org/10.47175/rielsj.v2i4.344

\author{
| Iswahyudi | \\ Faculty of Language and Arts, \\ Yogyakarta State University, \\ Yogyakarta, Indonesia \\ iswahyudi@uny.ac.id
}

\begin{abstract}
Karmawibhangga comes from the words karma and wibhangga. If karma can literally be interpreted as actions that come from causes and cause effects, then wibhangga is a designation for one of the holy books in Buddhism (Buddhist scripture). Literally karma can be interpreted as actions that come from causes and cause effects. In Buddhism, karma is the basic doctrine formulated and taught by Siddhartha Gautama. According to this doctrine, every living being has karma, both generated by himself and inherited from his ancestors. It is this karma that has caused samsara and is a barrier to attaining heaven or nirvana. Births in heaven and in hell seem to be at the core and there is a belief that some kind of hell is known in written sources both inscriptions and ancient manuscripts in Java. The state of life in heaven is marked by the kalpawrksa tree flanked by kinaras.

KEYWORDS

Karmawibhangga; Borobudur Temple; character building; heaven; hell
\end{abstract}

\section{INTRODUCTION}

In 1885 a number of reliefs at the foot of the Borobudur temple were rediscovered by J.W. Ijzerman. The demolition of the stone covering the foot of the temple was completed in five years and managed to find reliefs carved on 160 panels and before being closed, all reliefs were photographed by Kasian Cephas in 1890 - 1891. These reliefs have attracted the attention of researchers to identify them, including NJ Krom in 1920 and 1927 and Sylvain Levi in 1931 (Santiko, 2012: 3). Krom in his essay entitled Archaeologische Beschrijving van Borobudur (1920) argues that these reliefs are nothing but related to the teachings of the Law of Karma, which is a very important Law of Cause and Effect in Buddhism. Later Levi published a Sanskrit text from Tibet and Nepal, entitled Mahakarmawibhangga. During his stay in Kathmandu, Levi came across a Buddhist text and another in the possession of Rajguru Hemraj Sarman. After returning to France, Levi began to study the Buddhist texts and published them with their translations into French. The work of comparing the manuscript with the reliefs of Borobudur was submitted to Krom which in 1933 was published in a book entitled Het Karmawibhanga op Borobudur (Fontein, 1989:10).

In 1989, Jan Fontein re-examined the Karmawibhangga relief, because according to him there was a discrepancy between the scene in the panel and Levi's script. He did a study on several Chinese-language Tripitaka texts and it turned out that there are two manuscripts whose contents are close to Levi's Nepali text, namely the first translation of the Sutra on "the difference in the consequences of every action taught by the Buddha to Suka Manava", the title in Chinese is $\mathrm{Fu}$-shuo Ch'ang-che Yeh-pao Ch'a pieh-ching. The manuscript was translated into Chinese in 582 AD by Gautama Dharmaprajna, the son of Prajflaruci who came from India. This translation was republished in Taisho Tripitaka No. 80. The second 
manuscript is the Sutra on "the difference between the consequences of every good and bad deed", the Chinese title is Fen-pieh Shan-wo Pao-ying-ching. The manuscript was translated by a Cashmere priest named T'ien Shi-Tsai who came to China in 980 and lived there for 20 years. The translation was published in Taisho Tripitaka No. 81 (Fontein, 1989:13).

According to Jan Fontein's research, the two Sutras, especially Yeh-pao ch 'a-pieh-ching (T.BO) are very close to the scenes in the Karmawibhangga relief at the foot of Borobudur Temple. However, before comparing the manuscripts and reliefs, we will first explain the concept of karma and its outline at the foot of the Borobudur Temple. Karmawibhangga, karma means "action, behavior", and wibhangga means "flow, wave". Karmawibhanga is an explanation of the flow or waves of human life as a result of past life behavior. Every human action will result in the form of his birth after the perpetrator dies. He can be reborn as a beautiful or ugly human being, rich or poor, stupid or intelligent, and so on. He can be born as a god, as an animal, as a hungry ghost or preta, as an asura, born in hell, born in heaven, and so on. So, good or bad fate is determined by the actions (karma) of humans themselves. The Law of Karma or the Law of Cause and Effect applies to everyone, be it a king, noble, priest or commoner. In essence, the teachings of Karmawibhangga say that an action will have consequences.

\section{RESULTS AND DISCUSSION}

\section{Karmawibhangga relief}

The Karmawibhangga relief is a relief carved at the foot of the Borobudur Temple. In general, the temple does have a vertical section called the foot of the temple, the body of the temple, and the head (roof) of the temple. The foot of the temple at Borobudur symbolizes Kamadhatu, the human world bound by lust. The body part of the temple symbolizes Rupadhatu, the human world that is still bound by form but has been able to control lust. The topmost part, namely the roof which symbolizes Arupadhatu, represents the world of the gods as holy beings who are no longer bound to form and free from the bonds of lust. Simultaneously, the three parts of Borobudur Temple describe the spiritual journey of living beings, in order to get perfect enlightenment so that they become holy beings who are free from the cycle of rebirth and can achieve nirvana (Djaliati, 2012: 18-19).

The Karmawibhangga relief carved in 160 panels is not a series of scenes that narrate a continuous story, like the Lalitavistara relief on the walls of Borobudur Temple on the first floor. The hundred and sixty panels are snippets from a number of scenes about karma. Karma literally can be interpreted as an action that comes from a cause and gives rise to an effect. However, karma is actually not only produced by various forms of physical actions, but also thoughts and words.

In Buddhism, karma is the basic doctrine formulated and taught by Siddhartha Gautama. According to this doctrine, every living being has karma, both generated by himself and inherited from his ancestors. They cannot escape from karma, and it is this karma that determines the high and low of their dignity and quality of life. Karma has an effect that is not only felt by the perpetrator, but also the people around him and his environment. This is because one karma can push other karmas whose effects reach out in all directions. And vice versa that humans can be affected by the karma of other individuals. Karma is what has caused samsara and is a barrier to attaining nirvana (Iswahyudi, 2021: 7).

It can be further stated that Karmawibhangga comes from the words karma and wibhangga. If karma has been outlined above, then wibhangga is a term for one of the holy books in Buddhism. Thus Karmawibhanga is one of the scriptures in Buddhism that discusses karma, namely the moral law related to cause and effect. The book related to the law of cause and effect in question is Maha Karmawibhangga. The book is indeed a very 
important book in Mahayana Buddhism, so that the book is spread to various directions along with the spread of Buddhism itself, and has been translated into several languages.

The existence of the Maha Karmawibhangga book in one location may be a direct translation of the original book, but it can also be a derivative of the original book. For this reason, perhaps until now experts have faced obstacles in tracing which book was used as a reference for the artists in carving the Karmawibhangga Relief at Borobudur Temple. Previous research has only succeeded in identifying 23 of the 160 Karmawibhangga Relief panels that can be referenced with the Maha Karmawibhangga book. Apart from the various possibilities regarding the existence of the 23 panels, the fact that the other 137 panels that cannot be traced to exist in the Maha Karmawibhangga is more interesting.

By adhering to the genius ability possessed by the Javanese at that time, it is possible that the book that was the reference in making the Karmawibhangga Relief has been processed and interpreted in such a way as to produce a different picture from the original book. The existing differences should not be treated as a form of deviation, but as a compromise effort to be adapted to the needs and conditions of the people who are the targets of the teachings in the relief. In this regard, it is appropriate to assume that the Maha Karmawibhangga has undergone a localization process.

The process in question can also be identified through the setting of stories that describe the conditions of the local community and environment in Java. Although the story of Karmawibhangga itself is not a local story, it is a story originating from India. A number of studies that have been carried out on the elements depicted in the reliefs can almost entirely be found in the daily lives of local Javanese communities whose existence can still be traced to this day. Likewise, the depiction of human figures, both physical depictions and the accompanying cultural characters, shows the characteristics of the Javanese. Although the Karmawibhangga Relief is not a continuous narrative relief, the way it is read follows the tradition of reading narrative stories, which is read in a clockwise direction (pradaksina).

The reading starts from the entrance of the temple on the east side. The first panel of the Karmawibhangga Relief is placed on the south side of the door, while the 160th panel is placed on the north side of the door. Because there are four doors in Borobudur Temple, the hundred and sixty Karmawibhangga relief panels are distributed into four blocks. The first forty panels are on the block between the east door and the south door; the forty second panels are on the block between the south door and the west door; the forty third panels are on the block between the west door and the north door; and the last forty panels are on the block between the north door and the east door.

To understand the scenes in the panels of the Karmawibhangga Relief through secondary sources, an understanding of the nomenclature is needed. The mention of Relief Karmawibhangga uses the nomenclature of 0, as has been used by Krom since 1927 and is still being used by researchers until now. With this nomenclature, the mention of each panel starts from 0-1 and continues until 0-160.

The Karmawibhangga reliefs are carved on 160 panels depicting teachings on karma, the law of cause and effect, good and bad deeds. Read from the east to the right of the temple (pradaksina). The way to read it is arranged in such a way that one panel consists of two or three scenes and the leftmost scene is the result of the actions described in the previous scene (on the right). Each scene is bounded by a tree, or an upright object. In addition, all reliefs (160 panels) are grouped into two groups, namely (Santiko, 2012: 6-10):

1) The first group describes one effect from several causes.

According to Krom, this group starts from the 0-1 panel and ends with the 0-117 panel, while according to Jan Fontein it starts from the 0-1 panel until the 0-123 panel. 
2) The second group, starting from panels 0-118 (Chrome) or 0-124 (Jan Fontein) describes several effects that arise from one cause.

Jan Fontein translated the Chinese text ( $\mathrm{T}$ 80) and saw a match between the text and the relief scenes. Below will be given some examples of the first group $\{0-1-0-123\}$ : There are 10 actions that result in rebirth in a short life, namely 1) killing beings with one's own hands, 2) being influenced by others to commit murder, 3) likes to kill, 4) likes to see someone killed, 5) expects the death of someone he hates, 6) takes pleasure in the death of someone he hates, 7) causes someone to have an abortion, 8) encourages someone to have an abortion, 9) finds a temple to kill creatures, 10) encourage others to hurt each other. Those are the 10 actions that will result in short-lived rebirth.

In paragraph I (first) there is a match with the scene at the foot of Borobudur Temple No. 01-05. For example, in panels 0-2, the scene on the right depicts people hunting and cooking fish, on the left it shows the sadness of a group of people over the death of a small child (photo 1). In panels 0-3, depicts abortion, resulting in the death of children (photo 1) 2). The death of a young child (short age) is the result of the causes depicted in the 0-1-0-5 panel scenes. Panel 0-1 only describes the "cause", it looks like a depiction of someone putting something (a fish caught?) into a container which in Java is called an implant or wuwu. This 0-1 panel becomes one with the 0-2 panel, and as a result there is a 0-2 panel on the left.

Meanwhile, paragraph II mentions the opposite effect and cause of paragraph I, namely "people will be reborn as a long-lived human being" if they perform 10 opposite actions as referred to in paragraph II.

Paragraph I, and this can be seen in the reliefs of the panil temple 0-6 - 012. But how to describe "long life" the artist seems to have difficulty, so "long life" is described as a person with his family, with his servants and so on (Fontein, 1989:17).

For example, in relief $0-10$ there is a scene that depicts "blocking other people from killing", in the right-hand scene, three people are depicted helping someone from being beaten up, while the left-hand scene is the rebirth of the helpers as happy and long-lived people ( photo 3). Furthermore, in panels 0-15 there is a scene of a priest who forbids people from eating and drinking excessively, and as a result they will be reborn as sick people (scene on the left). The scene is part of paragraph III, it says there are 10 actions that can result in rebirth as a person who is always sick, including being prohibited from hitting other people, disappointing and making parents sad, happy to see other people sick or suffering, eating and drinking excessively which is said to be the phrase "eat again before the previous food has not been digested" (Fontein, 1989: 18).

On panel 021-024 there are reliefs that can be associated with the inscription virupa (bad face). The scene on the left of the reliefs shows a picture of a person with a bad face, as a result rebirth because he has done 10 prohibited acts, including always angry, dishonest, disrespectful to parents, damaging temple or stupa lamps and so on. In panels 0-24, there are scenes on the right of people destroying temple lamps, and scenes on the left of people with bad faces. In panels 0-26 there are rebirths as good and pleasant people, the results of good deeds, including "don't be hostile to others, give gifts of clothes, clean temples or priests' houses" and so on, a total of 10 goodness.

The causes and effects of the first group are still continuing, with the pattern of 10 forbidden actions resulting in harmful rebirth, followed by 10 good actions with pleasant results. This pattern is found in paragraphs I to XIX. Various unpleasant rebirths are found in panels 0-86, namely rebirth in hell (0-86-0-92\}, rebirth can be in the form of animals, for example rabbits, deer, cows, dragons, garudas and so on (panel 0 -93, 0-94) Reborn as a preta (starving ghost 0-095), then reborn as an asura, and as an ordinary human. 
Birth in heaven (svargga) is spoken of in three paragraphs (XX-XXII\}, (Fontein 1989:3446). An example is seen in panels 0-101-0-102. Rebirth in hell, apparently favored in Karmawibhangga, we can see in panel 0-109, that there is a belief that there are several types of hell known in written sources both inscriptions and ancient manuscripts in Java.

Then the second group, namely the part that suggests one action (cause) results in several consequences (0-124-0-160). This second part has just started on the reliefs on panels 0-124, which describes the act of worshiping stupas (chaityawandana) and Buddhist holy places with the result of obtaining 10 merits, depicted in reliefs 0-124-0-126, of whom will be born as people. importance/power (0-125), and birth in heaven . The state of heaven is marked by the kalpawrksa tree flanked by kinara-kinari (0-126).

In the second group, this Karmawibhangga scene contains various actions related to virtue, especially the giving of funds, namely alms to the poor, to priests, to holy places and so on. Each one will get about 10 good births as a result. Some of the funds in the reliefs are chattradana (giving an umbrella) to a priest on panel 0-127, vastradana (giving clothes) to a priest sitting under an umbrella (panil 0-135), relief 0138 about bhojanadana (giving food) to three priests , maladana (giving garlands) on reliefs 0-154, puspadana on reliefs 0-152, ghantadana, giving bells on reliefs 0-131, patakadana giving in the form of patokas (flags) on reliefs 0-142 and so on (Fontein 1989:60; Santiko, 2008:6). Giving alms, is one of the 10 Paramita, namely virtues that must be carried out by every Buddhist, especially Bodhisattvas who seek Buddhahood.

These ten Paramitas must be observed in tandem with the ten Bodhisattva paths (dasaboddhisattwabhumi). Therefore religion Mahayana Buddha is also known as Paramitayana. According to research by Jan Fontein (1989), the text of Yeh pao-ch 'a-piehching (T.80), provides many explanations for scenes that previously could not be understood. However, there are several scenes or figures that are carved differently from the script, for example the garuda and dragon appear in the reliefs as a form of rebirth (panil 0-94). Both animal figures are important figures in Javanese myth, but neither is mentioned in the text. Rebirth as both animals is confusing, as punishment or vice versa? (Fontein 1989).

In the History of Art, the development of art styles is closely related to the condition of the society in which the art concerned was born, not only depending on the spirit of the era, but also depending on the rulers (kings, and/or priests) (Sedyawati 1986:3-6). This opinion can explain some of the differences between the script and the relief scene at Borobudur Temple. The pastor's intervention can also be seen in the different concepts of good and evil/evil. In the text the two things must be balanced, but in Karmawibhangga Borobudur, good is much more emphasized than evil (Fontein, 1989:70).

Likewise the description of the characters, the scenes are often not the same as the script. This is because first, the teaching of the Law of Cause and Effect is for the ancient Javanese people from all walks of life, so what is depicted must be digested by them. Second, the reliefs on the walls of the temples depict the daily life of the ancient Javanese people, which are well known by the silpins, so that they are depicted perfectly. The Chinese manuscript translated by Jan Fontein is very helpful in analyzing the Karmawibhangga reliefs of Borobudur Temple. However, the question arises, which script was used by the Borobudur silpins, the Chinese script (T.80), or the Sanskrit text before being translated into Chinese by Gautama Dharmaputra?. The question arose because at the top of the panel there were short inscriptions (about 50 pieces) used to guide the artists, written in Old Javanese characters and Sanskrit words. 


\section{The concept of relief iconography in Buddhism}

Karmawibhangga is believed to be a collection of the Buddha's own teachings on the Law of Cause and Effect, and reminds people, especially pilgrims, of which actions are good and which ones should be avoided. However, the episode depicted is the fairy life of the ancient Javanese people in the VIII-X century AD, which is related to the teachings of the Law of Cause and Effect. The scenes in the panel are also very important to see the behavior of the ancient Javanese people at that time, including religious activities, livelihoods, social structures, clothing, living equipment, types of flora and fauna (Kempers 1976: 235-279; Santiko, 2008:3).

There are many things that can be researched, but in this essay it will only be related to their religious activities. The teachings of Karmawibhangga carved by ancient Javanese silpins on the walls of the foothills of Borobudur Temple emphasize good and bad/evil behavior. Attitudes that are addressed to the sacred building, to the clergy, to parents, to fellow human beings, to oneself, and to other creatures. Behavior that has both good and bad consequences for the perpetrator, various consequences associated with the perpetrator's rebirth.

Religious figures who are important figures to receive respect, are often depicted in the Karmawibhangga reliefs. In the reliefs, there are many depicted not only monks, but also non-Buddhist priests (Shiva), even ascetics (rsi) in large numbers. Based on observations, the number of Buddhist priests (bhiksu) is only half the number of other religious people, which is about 18. They are depicted with bald heads, wearing robes that are open on their right shoulders, holding shells for begging, sometimes seen wearing sticks and carrying prayer beads. For example, reliefs of three monks can be seen in reliefs 0-55. But besides that, there is a relief of a person with the characteristics of a monk on panels 0-73, but wearing earrings and mustache accessories, so it is doubtful whether the character is a monk.

Beside the monks, several figures of Shiva's priests are seen, in general they wear jatomakuta (hair crowns), upawita (caste ropes), as seen, among others, in reliefs 0-26. There are about 29 Shiva priests, and are generally described as giving sermons. Then there are other figures, namely ascetics called sramanas in Buddhism or sages both Buddhist and Hindu. In Buddhism, there are also rsi with the following characteristics: dressed in bark, chewing sandalwood, holding prayer beads and other appropriate equipment ( Magetsari, 1998:112). That rsi (muni) had an important position in the life of the ancient Javanese people around the IX-X centuries is described in the kakawin Ramayana. Ascetics (rsi) are often referred to as Maharesi or Mahamuni, are considered experts in literature and religion, and know about various types of ceremonies (tumoli ri yajna kabeh). They live in a remote patapan (Santoso 1980:40 etc.).

Who is this sage? In the inscription of King Airlangga, they are called "clothed with bark" (walkali, walkalika) and are distinguished from the priests of Shiva and Buddha, although the three are referred to together, in groups of three namely rsi-saiwa-sogata and group of four namely rsi-saiwa sogata- mahabrahmin. The meaning of the rsi figure in Java is somewhat different from the meaning in India. If in India, sages are mythical figures of Vedas and various religious knowledge, for example Narada, Marici, Kasyapa, Pulastya, Bharadvaja and so on. However, in Java there are 2 kinds of rsi, namely mythical figures such as those in India, and another group are ascetics (muni) who have entered the wanaprastha and Sanyasin stages of life (stages three and four), so they are not just any ascetic (Santiko 1996) . In reliefs in temples during the Majapahit era, for example Panataran Temple, some called rsi wore robes and turbans, but some were not robed, their hair was loose, as in the scene "Bubuksah and Gagangaking", a relief on the Batur of Panataran temple. 
Back in the Karmawibhangga relief, in addition to Reverend Shiva with the characteristics mentioned above, there are bare-chested figures, and generally carry umbrellas, they may be ascetics, for example reliefs 0-49, 0-54, 0-55, 0-117. Although the exact number of priests of Shiva and how many ascetics is not clear, the number of these non-monk clergy is almost double the number of the monks themselves. They, both Shiva priests and ascetics, give advice, receive funds, are respected by residents from various social strata. The Karmawibhangga relief is a relief about the Law of Cause and Effect, a teaching about the Law of Karma that should be known by all temple visitors during the Borobudur period, or later. But the foot of the temple with the relief is closed, only left a little in the southeast corner to see. What is the reason for closing?. There are those who argue to maintain stability so that the large temple building does not collapse. We can understand this reason, because Borobudur Temple stands on a hill without a foundation.

Temples are generally built on a foundation by compacting the soil, as is the case with Prambanan Temple which has a foundation of six meters deep. But the foundation of Borobudur Temple is made differently, the temple is erected directly on a hill, which is shaped according to the desired temple shape by cutting the high hillside and enclosing the low one. The foundation of the outermost temple is made into the ground to a depth of approximately one meter. The foundation is superimposed on the rock (bedrock), while the top of the temple is superimposed on several layers of stone. However, some argue that this is related to the teachings of the 10 levels of Bodhisattva (dasabodhisattwabhumi) as stated by J.G. de Casparis and Nurhadi Magetsari. (Magetsari 2000:42-43). But the most reasonable assumption is purely for technical reasons, if it is seen that many relief panels have not been finished carving, some even have not been carved at all. It is possible that before all the panels have been completed, there have been a number of serious technical difficulties that have to be faced by the planners and founders, resulting in the sturdiness of the building being jeopardized. The foot of the temple, which was decorated with 160 relief panels, was then filled and covered with approximately 13,000 cubic meters of stone to strengthen the construction of the building (Mindra, 1987). The closing part is now the undag and fault of the Borobudur Temple.

\section{Life in Heaven and in Hell}

There are two major aspects that exist in the depiction of society in the Ancient Mataram period, such as religious aspects and non-religious aspects. The relief panels in the religious aspect emphasize more on the sacred teachings of Buddhism adopted by the ancient Mataram community. The non-religious aspect that is described is in the form of people's daily lives in meeting their respective needs. Traditional values are interpreted as expressions of gratitude to the Creator in the form of major ceremonies such as in the determination of sima or other traditions. This is also described in the form of reliefs, because relief is a medium that can be a bridge between ordinary people and the authorities. In addition to reliefs, the media generally used are inscriptions, temples and lontar manuscripts. Such media is also a means of facilitating the community in providing lessons to the next generation. (Kusuma, 2020:114-115)

Broadly speaking, the Karmawibhangga Relief describes human life and the environment and their behavior, both towards the environment and towards fellow humans. What is depicted in this relief is not merely a record of behavior as mentioned, but also a medium of learning to achieve a better level of life based on the teachings of Buddhism, more specifically based on the law of cause and effect. By looking at the location of its placement which is carved at the foot of Borobudur Temple, it can be stated that the target of the 
teachings contained in it are living beings in the mortal world, whose lives are still oriented to material (form) and are controlled by desire or lust.

Before discussing further about what behaviors are described in the Karmawibhangga Relief, it is necessary to first know the description of the people who are the perpetrators. There are at least three classes in society, namely the clergy (priests, monks, sages), the ruling class (nobles, village heads, cakrawartins, landlords), and the general public with various professions. A number of professions that can be identified through the Karmawibhangga Relief panels include farmers (0-65), traders (0-1), musicians (0-39), dancers (0-72), acrobats (0-52), buskers (0-117), healers (0-18), executioners (0-4), traditional birth attendants (0-3), and servants (0-58). Of course there are many other professions that are not described explicitly, but their existence can be interpreted indirectly. The large variety of pottery containers spread over many panels, for example panels 0-66, gives an indication of the pottery-making profession. Likewise, the profession of making clothes and jewelry. Studies conducted on a number of inscriptions that were contemporaneous with Borobudur Temple found no less than 100 types of professions undertaken by the community.

The behavior shown by each group can show its own duties and obligations. The clergy, for example, are tasked with providing teaching about religion and knowledge from the book, as described, among others, on panels $0-55$ and $0-60$. This group is also obliged to give advice (0-46) and provide themselves as a place to exchange ideas (0-49). The ruling class is a group that has resources, both power resources and property. With their power and property, the ruling class has the obligation to provide livelihoods to the other two groups, by giving alms and alms. Charity and alms are given to the clergy (0-12) and the poor $(0-32)$ in various forms. It can be groceries, clothes, money (0-107) and even jugs (0-115). Apart from donations or alms, the clergy also receive offerings from the community, both from the ruling class and ordinary citizens, such as in the form of flowers, as shown among others through the 0-7 and 0-31 panels. Charity and alms can be given directly or by ordering subordinates of the authorities to give the intended charity and alms, as exemplified by the 0-11 panel. While the majority of the community, because what they have is the energy to produce goods and services, this group has a role as a provider of goods and services needs (0-27 and 0-57) both to the clergy and the ruling class. Panel 0-50, for example, describes the general population who harvest jackfruit and give the jackfruit as an offering to the nobility.

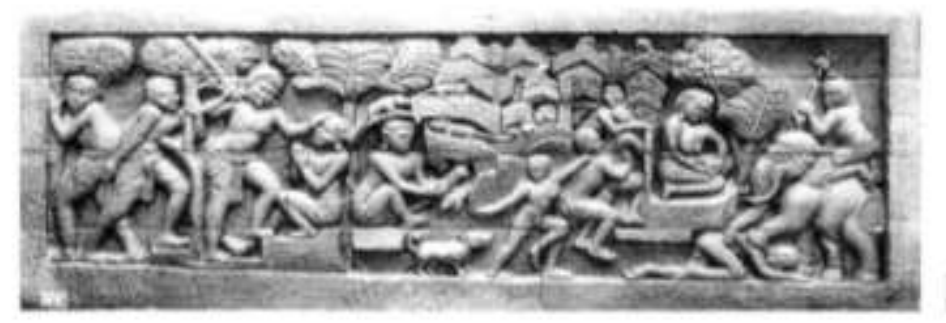

Figure 1: Situations in Hell Sanjiva and Kalasutra

Life in hell full of torments is seen in panel 86 because in Buddhism there are three important concepts that are always used as the basis for teaching, namely karma, samsara and nirvana. Karma is concerned with the balance between bad and good human actions during his life. If the consideration between good and bad turns out to be more evil deeds then the next life is lower in level than human life, even if it is too extreme then humans will get the predicate of a major sin which will later be punished in hell. In Buddhism, there are eight major sins whose successive levels are Sanjiva, Kalasutra, Sanghaya, Raurava, Maharaurava, Tapana, Pratapana and Avici. In these reliefs Sanjiva is categorized as the first 
hell and Kalasutra is the second hell. The categories of sins in Sanjiva's hell agenda are those who commit crimes against body, mind, words, kill humans, riot and injure others. In this relief, to the left of the sinner, two people have been prepared, swinging a sword and a club, one of them has hit his head with a hard object, while the other sinner will also be stabbed with a sharp object in both eyes and also bitten by a wild dog. Furthermore, on the right side is the great sin of Kalasutra, in which these categories of sins include not respecting Buddha, priests and parents, lying, torturing, killing, burning living animals, injuring parents and friends, speaking with evil intentions and stealing. In this relief, two pairs of men and women are visualized who are pitted against each other to the death (Iswahyudi, 2021: 81-82).

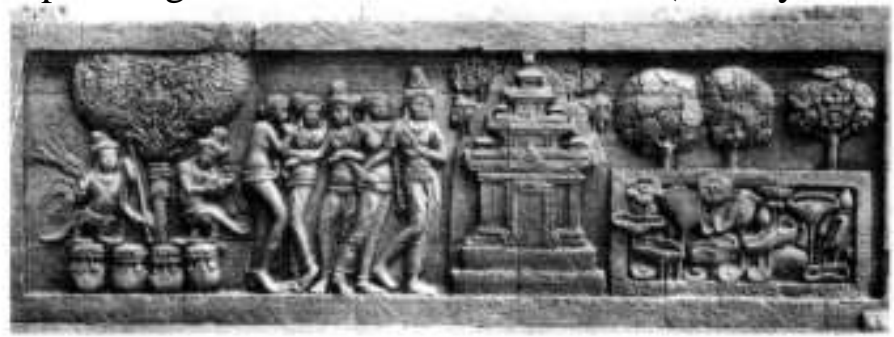

Figure 2. Situations in the Hell of Sanghata and Raurava

Panel 87 depicting the Sanghata and Raurawa hell. In this relief depicted a human being trampled by an elephant and crushed by a mountain because he had tortured fellow humans. Details in this relief, the Sanghata and Raurawa hells are the 3rd and 4th hells of the eight hells. The eight hells are the sanjiva, kalasutra, sanghata and raurava hells, maharaurava, tapana, pratapana and avici (Krom, 1927: 67). Sanghata hell is a punishment for people who are evil because of hate, jealousy, anger, vile, evil thoughts, animal killers, especially insects and adulterers. As a form of punishment is that the mountain will fall and fall on them, and the elephant beast will trample on it until its body is flat to the ground.

Raurava Hell is a place of punishment for murderers, poisoners, thieves, robbers, house hijackers, debtors, animal abusers and liars. The form of punishment is that they will be boiled in a pot, fried and burned. In this relief, a person is seen hugging a tree on his left. Likewise with the person next to him, but with one hand. Then there was someone who was carrying a mace in his right hand, while in his left hand he was holding the head of the person in front of him. The mace was raised as if to be swung and struck at the person who was squatting in front of him. The squatting person leaned against a tree trunk and acted as if he was begging for mercy to the one with the mace. On the right, there is a person sitting with something around the person who looks like he is imprisoned and there are small animals that are thought to be rats. The person is exterminating rats. Then there is a relief that visualizes four people being chased by a dog. They looked very scared and tried to climb to a higher place, above the person at the back was a face with eyes closed and mouth open like a helpless person.

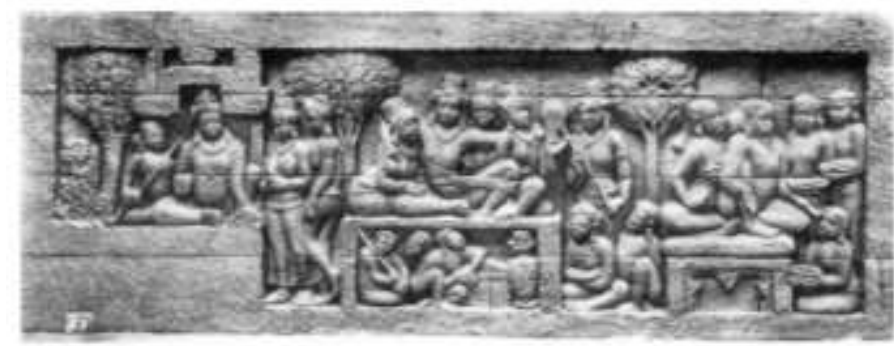

Figure 3. The state of heaven with its inhabitants, gods, kinara-kinari under a tree. It looks like a building surrounded by clouds. There is an inscription svargga 
Panel 147 is describing heaven (svargga). In this relief, the state is in heaven with its inhabitants, the gods and heavenly beings, kinara-kinari who are under a tree. It looks like a building surrounded by clouds. On the left is a pond full of lotus flowers. The detail in this relief is that some of the princesses or maybe the angels are in a garden with a beautiful pond that looks like they are going to a building like a temple. Two pairs of kinara-kinari were seen playing music. The musical instruments used are a siter-bar and a small cymbal.

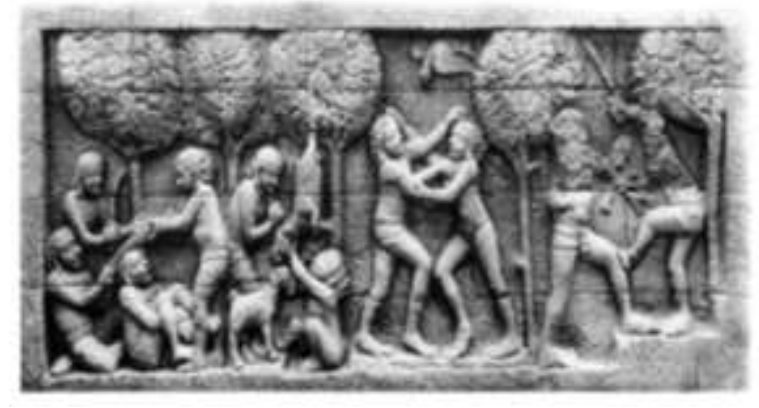

Figure 4. Two priests receive alms from three men. Conditions in heaven and the other inhabitants of heaven. There is an inscription svargga

Panel 153 describes the giving of alms and heaven. In this relief, two priests who are dressed simply are receiving donations from three men. Another scene depicts conditions in heaven with the gods and other heavenly inhabitants.

\section{CONCLUSION}

The teachings of the Law of Karma at Borobudur Temple are depicted in various scenes that were well known to the people at that time, because they were depicted in various scenes of their daily life. What is depicted in the Karmawibhangga relief is the daily life of the ancient Javanese people, so naturally what is depicted are things that are in accordance with their attitudes and way of life. They seem to have great respect for other priests in addition to monks, and also respect the ascetics who far outnumber the monks. Based on the short inscription carved on the panel, which is thought to be a guide for the silpins, it can be stated that the silpins who carved the temple reliefs were Javanese (Indonesians) who understood the instructions given. The inscription is written in Old Javanese characters, and Sanskrit words without suffixes, which should be added to the words. For example, the word "swargga" for people who are familiar with Sanskrit, for example Indians themselves, will be confused about what scene to carve, whether in heaven (svargge), heavenly beings (svarggah), or others. This is partly as evidence that the Javanese/Indonesians themselves were the carvers at the Borobudur temple.

\section{REFERENCES}

------- (1987), Yang Selalu Menggapai dari Balik Kaki Candi Borobudur, dalam Karmawibhangga Candi Borobudur Gambaran Masyarakat Jawa Abad ke-9. Jakarta: Bentara Budaya-IAAI GEMABUDHI.

(1996), Religious Life of the Rsis in the Majapahit Era, In Southeast Asian Archaeology in 1996. Proceedings of the 6'h International Conference of the European Association of Southeast Asian Archaeologists. Leiden 2-6 September.

-- (2000), Candi Borobudur Ditinjau dari Sudut Buddhologi, Simposium Sehari Rahasia

Dibalik Keagungan Borobudur. Dharmasena Trisakti. 
Anom, IGA. (2000). Candi Borobudur Sekilaspintas, Simposium Sehari Rahasia di balik Keagungan Borobudur. Dharmasena Trisakti.

Badil, Rudi dan Nurhadi Rangkuti (1992), The Hidden Foot of Borobudur. Jakarta: Penerbit Katalis, 2"d edition.

Balai Konservasi Borobudur (2012), Adegan dan Ajaran Hukum Karma Pada Relief Karmawibhangga, Seri Terbitan Candi Borobudur - 4

Bernet Kempers, A.J. (1973). Borobudur: Mysteriegebeuren insteen Verval en Restauratie Oudjavaans volksleven . Wassenaar: Servire B.V.

Bernet Kempers, A.J. (1976). Ageless Borobudur, Buddhist Mystery in Stone. Servire Wassenaar.

Coomaraswany, Ananda K. (1975), Early Indian Architecture: Palaces. T.k.p: Munshiram Manoharlal

De Casparis, J.G. (1950). Inscripties uit de Sailendra-tijd. Bandung.

Fontein, Jan (1989). The Law of Cause and Effect in Ancient Java . Koninklijke Nederlandse Akademie van Wetenschappen Verhandelingen Afdeeling Letterkunde. Nieuwe Reeks, deel 140. Amsterdam: North Holland Pub.

Iswahyudi (2021), Karmawibanggha Borobudur. Yogyakarta: Graha Ilmu

Iswahyudi, I. (2021). Metal Craft Studio Development: An Idea to Prepare a Teaching Factory Education Concept Model in the Craft Education Study Program, Yogyakarta State University. Randwick International of Education and Linguistics Science Journal, 2(3), 339-357. https://doi.org/10.47175/rielsj.v2i3.302

Johnstone, Marea A. (1981). Borobudur: an Analysis of the Gallery I Reliefs, Pelita Borobudur Seri C No.3. Jakarta: Proyek Pelita Pemugaran Candi Borobudur, Depertemen Pendidikan dan Kebudayaan.

Kandahjaya, Hudaya (1995). The Key Mater for Reading Borobudur Symbolism. Jakarta: Yayasan Penerbit Karaniya.

Klokke, Marijke J. dan Karel R.van Kooij,eds. (2001). Fruits of Inspiration: Studies in Honour of Prof J.G. de Casparis. Groningen: Egbert Forsten.

Krom, N.J. (1920). Beschrijving van Borobudur I: Archaeologische Beshrijving. 1920,1927.

Kusuma, Theodorus Aries Briyan Nugraha Setiawan Kusuma et al, Komunikasi visual dalam relief Karmawibhangga Candi Borobudur. Jurnal Panalungtik, Vol. 3(2), Desember 2020, $105-116$

DOI: https://doi.org/10.24164/pnk.v3i2.44

Levi, Silvain (1931). The Karmavibhanga Illustrated in The Buried Basement of The Candi Borobudur, dalam Annual Bibliography oflndian Archaeology IV.

Levi, Silvain (1932). Maha-Karmavibhangga et Karmavibhangopadesda. Paris: Librairie Ernest Leroux

Magetsari,Nurhadi (1998). Candi Borobudur, Rekonstruksi Agama dan Filsafatnya. Jakarta: Fakultas Sastra Universitas Indonesia

Miksic, John (1991). Borobudur: Golden Tales of the Buddhas. Singapore: Peri plus Edition (HK), Ltd.

Mindra Faizaliskandar (1987). Kronik Borobudur, dalam Karmawibhangga Candi Borobudur Gambaran Masyarakat Jawa Abad ke-9 . Jakarta : Bentara Budaya-IAAI GEMABUDHI.

Munandar, Agus Aris (2011), Adegan-adegan Relief Mahakarmavibanggha Candi Borobudur: Tinjauan terhadap penataan tataran adegan dan makna simboliknya. Jakarta: Departemen Arkeologi Fakultas Ilmu Pengetahuan Budaya Universitas Indonesia 
Nugrahani, Djaliati Sri (1988). Jenis-jenis Binatang pada Masa Jawa Kuna : Studi Kasus melalui Relief Candi Borobudur dan Candi Prambanan. Skripsi S1 Jurusan Arkeologi Fakultas Sastra UGM.

Nugrahani, D S. (2012), "KARMAWIBHANGGA : Peringatan Bagi Perilaku Manusia" dalam Balai Konservasi Borobudur, Adegan dan Ajaran Hukum Karma Pada Relief Karmawibhangga, Seri Terbitan Candi Borobudur - 4

Santiko, Hariani (2008), The Religious Atmosphere of the Karmawibhanga Reliefs of Borobudur, International Seminar on Karmawibhanga, 1-3 July .

Santiko, Hariani (2012), "RELIEF KARMAWIBHANGGA DI CANDI BOROBUDUR: Identifikasi Adegan dan Ajaran Hukum Karma" dalam Balai Konservasi Borobudur, Adegan dan Ajaran Hukum Karma Pada Relief Karmawibhangga, Seri Terbitan Candi Borobudur - 4

Santoso, Soewito (1980). Ramayana Kakawin, 3 vols. Issued under the auspices of the Institute of Southeast Asian Studies, Singapore and the International Academy of Indian Culture, New Delhi.

Sayadav, Ven. Mahasi. The Theory of Karma, in Buddhism Studies : Buddha Dharma Education Association and Buddha Net. dalam Soekmono, 1976. Chandi Borobudur, A Monument of Mankind. Amsterdam :van Gorcum and the UNESCO Press, Paris .

Sedyawati, Edi (1986). Pengarcaan Ganesa Masa Kadiri dan Singasari, Sebuah Tinjauan Sejarah Kesenian. Disertasi UI.

Soekmono (1976). Chandi Borobudur. Amsterdam : The Unesco Press.

Van Erp, Th. (1931). Berschrijving van Borobudur. 's Gravenhage.

Yun, Hsing (1999). Conditionally : The Law of Cause and Effect. California-USA: Buddha's Light Publishing. 